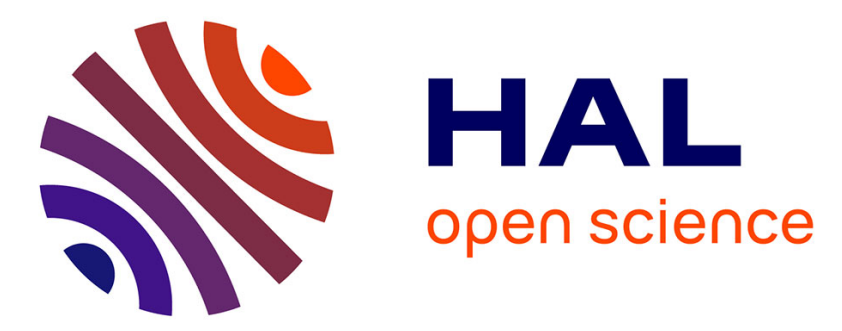

\title{
Adult weight gain in relation to breast cancer risk by estrogen and progesterone receptor status: a meta-analysis
}

Alina Vrieling, Katharina Buck, Rudolf Kaaks, Jenny Chang-Claude

\section{To cite this version:}

Alina Vrieling, Katharina Buck, Rudolf Kaaks, Jenny Chang-Claude. Adult weight gain in relation to breast cancer risk by estrogen and progesterone receptor status: a meta-analysis. Breast Cancer Research and Treatment, 2010, 123 (3), pp.641-649. 10.1007/s10549-010-1116-4 . hal-00565900

\section{HAL Id: hal-00565900 \\ https://hal.science/hal-00565900}

Submitted on 15 Feb 2011

HAL is a multi-disciplinary open access archive for the deposit and dissemination of scientific research documents, whether they are published or not. The documents may come from teaching and research institutions in France or abroad, or from public or private research centers.
L'archive ouverte pluridisciplinaire HAL, est destinée au dépôt et à la diffusion de documents scientifiques de niveau recherche, publiés ou non, émanant des établissements d'enseignement et de recherche français ou étrangers, des laboratoires publics ou privés. 


\section{Adult Weight Gain in Relation to Breast Cancer Risk by Estrogen and Progesterone Receptor Status: \\ a Meta-Analysis}

Alina Vrieling, Katharina Buck, Rudolf Kaaks, Jenny Chang-Claude

Division of Cancer Epidemiology, German Cancer Research Center, Heidelberg, Germany

Key words: $\quad$ adult weight gain; breast cancer; estrogen receptor; progesterone receptor; meta-analysis

Word count abstract: $\quad 250$

Word count text: 2824

Correspondence to:

Dr. Ir. Alina Vrieling

German Cancer Research Center DKFZ

Division of Cancer Epidemiology

Unit of Genetic Epidemiology

Im Neuenheimer Feld 280

69120 Heidelberg

Germany

Phone: $\quad+496221422208$

Fax: $\quad+496221422203$

e-mail: $\quad$ a.vrieling@dkfz-heidelberg.de 


\section{ABSTRACT}

Purpose: Adult weight gain is positively associated with postmenopausal breast cancer and inversely associated with premenopausal breast cancer risk. To date, no meta-analysis has been conducted to assess this association by estrogen receptor (ER) and progesterone receptor (PR) status.

Methods: We searched PubMed for relevant studies published through March 2010. Summarized risk estimates $(\mathrm{RE})$ with $95 \%$ confidence intervals $(\mathrm{Cls})$ were calculated using random effects or fixed effects models.

Results: We retrieved nine articles on weight gain from adulthood to reference age and ER and/or PR defined breast cancer risk, reporting on three prospective cohort studies and eight case-control studies. Comparing the highest versus the lowest categories of adult weight gain, risk was increased for $\mathrm{ER}^{+} \mathrm{PR}^{+}$and $\mathrm{ER}^{+}$tumors combined ( 11 studies; $\mathrm{RE}=2.03,95 \% \mathrm{Cl}=1.62,2.45$ ). Statistically significant heterogeneity ( $p_{\text {heterogeneity }}=0.002$ ) was shown between risk estimates for a mixed population of pre- and postmenopausal women combined (4 studies; RE $=1.54$, $95 \% \mathrm{Cl}=0.86,2.22)$ and for postmenopausal women only (7 studies; $\mathrm{RE}=2.33$; $95 \% \mathrm{Cl}=2.05,2.60)$. Risk for ER'PR tumors among postmenopausal women was also slightly increased ( 7 studies, $\mathrm{RE}=1.34,95 \% \mathrm{Cl}=1.06,1.63$ ), but statistically significantly different from risk for $\mathrm{ER}^{+} \mathrm{PR}^{+}$tumors ( $p_{\text {heterogeneity }}<0.0001$ ). No associations were observed for $E R^{+} P R^{-}$tumors whereas risk for $E R^{-} P R^{+}$tumors could not be assessed.

Conclusion: The association between adult weight gain and postmenopausal breast cancer risk is heterogeneous according to ER/PR status and stronger for $E R^{+} \mathrm{PR}^{+}$ than for ER'PR' tumors. 


\section{INTRODUCTION}

Body weight is an established risk factor for postmenopausal breast cancer whereas it is inversely associated with premenopausal breast cancer risk (1]. This may be due to differential effects of obesity on circulating endogenous estrogen levels according to menopausal status [2]. In postmenopausal women, estrogen is mainly synthesized by adipose tissue. Fatter women have larger adipose stores than leaner women, resulting in higher circulating levels of estrogen and lower levels of sex hormone-binding globulin (SHBG). In premenopausal women, estrogens mainly originate from ovarian synthesis, and levels are much higher than after menopause. However, overweight or obese premenopausal women are more likely to have anovulatory cycles and a greater clearance rate of estrogens by the liver compared to normal-weight women, resulting in lower levels of circulating estrogen and progesterone.

A recent meta-analysis has shown that the association between body mass index (BMI) and breast cancer risk is also heterogeneous according to estrogen receptor (ER) and progesterone receptor (PR) status [3]. Higher BMI was associated with higher risk for $\mathrm{ER}^{+} \mathrm{PR}^{+}$tumors in postmenopausal women but had a protective effect on $\mathrm{ER}^{+} \mathrm{PR}^{+}$tumors in premenopausal women. By contrast, no associations were observed for ER'PR tumors.

Adult weight gain is thought to be a better measure to assess adiposity and its metabolic consequences than BMI [4]. BMI reflects both lean and fat mass whereas adult weight gain largely reflects an increase in body fat independent of BMI [4]. Several studies examining both adult weight gain and adult BMI in the same study population have found weight gain to be an equivalent $[5,6]$ or stronger $[4,7-10]$ 
predictor of postmenopausal breast cancer risk than recent BMI. Adult weight gain has been inversely associated with premenopausal breast cancer risk [11].

Ten studies have investigated the association between adult weight gain and breast cancer risk according to ER/PR status of the tumor [12-21], and no systematic review or meta-analysis has been conducted thus far. Results of these studies were inconsistent, however, a limitation was that the number of non-ER+PR tumors in individual studies was mostly small and comparisons for these groups were likely to be underpowered. Therefore, the aim of this meta-analysis was to investigate whether the association between adult weight gain and breast cancer risk differed according to ER/PR status of the tumor.

\section{MATERIALS AND METHODS}

\section{Selection of studies}

A systematic PUBMED search was performed to identify epidemiologic studies published through March 2010 that reported on the association between adult weight gain and risk for breast cancer defined by ER/PR status. We used a combination of the Medical Subject Headings (i.e., breast neoplasms, body weight, body mass index, estrogene receptors, progesterone receptors) and also searched for related key words in title and abstract. The query retrieved 899 articles. In addition, cited references in retrieved articles were reviewed to identify possible further articles that may have been missed in this search. Eligible publications were assessed independently by two reviewers (AV, KB). Studies were included in the meta-analysis if they presented data from a prospective cohort or case-control study on the association between adult weight gain and ER and/or PR defined breast 
cancer risk. Studies that did not provide risk estimates (REs) for quantiles of adult weight gain were excluded.

\section{Data extraction and classification}

From each publication, we extracted the following information: the name of the first author, the year of publication, the country where the study was conducted, the major ER/PR assay, the name of the cohort study / the type of case-control study, years of follow-up (cohort studies), years of data collection (case-control studies), the number of overall cases, the study size (cohort studies), the number of controls (case-control studies), age, menopausal status, the weight gain categories studied, the effect estimates, and the adjusted factors. Relative risks or odds ratios and $95 \%$ confidence intervals $(\mathrm{Cl})$ from regression models were extracted and used for the subsequent analyses. The most fully adjusted risk estimates (REs) and confidence intervals for the highest quantile compared to the lowest quantile from each study were used for the meta-analyses. From the REs, the standard error of the estimate (SEE) was directly derived as SEE $=[\log (95 \% \mathrm{Cl}$, upper limit $)-\log$ (95\% Cl, lower limit)] / 3.92 and was employed in the calculation of the pooled estimates.

\section{Statistical analysis}

All analyses were carried out using the "meta" and "rmeta" packages of the statistical software environment $R$ (version 2.7.1) [22]. The statistical analyses included a test of heterogeneity to determine whether the study results (of groups) were significantly heterogeneous. The correct model for the combination of single study results to a common pooled estimate could thereby be determined. Several 
statistical and quantifying measurements were used to assess heterogeneity of a set of point estimates together with the respective standard errors, i.e., the $\mathrm{T}^{2}$ heterogeneity estimator, the $Q$ statistic yielding a (two-sided) $p$-value for heterogeneity, and the $\mathrm{I}^{2}$ index [23].

Weighting was performed by the inverse variance method [24] based on two commonly used models: the fixed effects model [25] and the random effects model [26]. In the prior model, one assumes that the effects are all in the same direction and of the same magnitude and are thus results of a common pooled effect. In the latter model, by contrast, there is no assumption that the effects are of identical direction and magnitude. Thus, in the random effects model the study results are combined in a more independent way by allowing variability within and heterogeneity between studies, respectively. Fixed effects models were used when heterogeneity was low ( $p$-value $>0.1$ ). Otherwise, random effects models were used. The individual study results as well as the combined pooled estimates were illustrated in forest plots. We calculated a pooled estimate for prospective cohort studies, casecontrol studies, and all studies combined. We initially included studies defined by joint ER/PR status and ER status only, and studies in mixed populations (pre- and postmenopausal women combined) and in postmenopausal women. Subsequently, we performed sensitivity analyses including only studies defined by joint ER/PR status or studies restricted to mixed populations or postmenopausal women, separately. For subgroup analyses, differences between the pooled REs were determined by the $Q$ statistic.

In addition, a sensitivity analysis was conducted to investigate publication bias of the included studies. This was visualized using a funnel plot $[27,28]$ and quantified using weighted linear regression of the effect estimate on its SEE [29]. 


\section{RESULTS}

\section{Characteristics of studies}

We retrieved 10 articles on adult weight gain and risk of breast cancer by ER/PR status [12-21]. One article did not provide risk estimates for quantiles of adult weight gain, and was therefore excluded [21]. In total, 9 articles (including 11 studies) on adult weight gain (10 from early adulthood, 1 from age 50 to reference age) and risk of breast cancer by ER/PR status were included in the meta-analysis (Table 1). Three of these studies were prospective cohort studies [12-14], and eight were population-based case-control studies [15-20]. Three case-control studies defined breast tumours by ER status only [18, 20], and nine studies by joint ER/PR status $[12-17,19]$. Four studies were conducted in a mixed population of pre- and postmenopausal women $[16,20]$, there were no studies that included only premenopausal women, and seven studies included only postmenopausal women $[12-15,17-19]$. All studies were conducted in the US, except for one study that was conducted in Sweden [19]. The number of cases with known ER/PR status ranged from 170 to 651 among the prospective cohort studies, and from $210\left(E R^{+} P R^{+}\right.$and ER'PR' only) to 1,001 among the case-control studies.

\section{$E R^{+} P R^{+}$tumors}

Random effects models were used to assess the association between adult weight gain and ER-positive breast cancer risk. Adult weight gain was associated with an increased risk for $\mathrm{ER}^{+} \mathrm{PR}^{+}$and $E \mathrm{R}^{+}$tumors combined (11 studies; $\mathrm{RE}=2.03$, $95 \% \mathrm{Cl}=1.62,2.45$, Pheterogeneity $_{2}$ 0.0001) (Figure 1, Table 2). Restricting our analyses to $E R^{+} P R^{+}$tumors slightly increased the risk estimate (8 studies; $R E=2.22$; $95 \% \mathrm{Cl}=1.83,2.61$, pheterogeneity $<0.0001)$. 
When comparing results for a mixed population of pre- and postmenopausal women combined and for postmenopausal women only, we found statistically significant heterogeneity $\left(p_{\text {heterogeneity }}=0.002\right.$ ) between risk estimates for the mixed population (4 studies; $\mathrm{RE}=1.54,95 \% \mathrm{Cl}=0.86,2.22$, pheterogeneity $<0.0001$ ) and for postmenopausal women only ( 7 studies; $R E=2.33 ; 95 \% \mathrm{CI}=2.05,2.60$, pheterogeneity $=0.0024)$.

\section{$E R^{-} P R^{-}$tumors}

Fixed effects models were used to assess the association between adult weight gain and ER-negative breast cancer risk. Adult weight gain was associated with an increased risk for $\mathrm{ER}^{-} \mathrm{PR}^{-}$and $E \mathrm{R}^{-}$tumors combined (11 studies; $\mathrm{RE}=1.36$, $95 \% \mathrm{Cl}=1.14,1.58$, pheterogeneity $=0.14)($ Figure 2, Table 2$)$.

Results were not statistically significantly heterogeneous $\left(p_{\text {heterogeneity }}=0.92\right)$ for the mixed population of pre- and postmenopausal women combined (4 studies; $\mathrm{RE}=1.32,95 \% \mathrm{Cl}=0.74,1.89$, pheterogeneity $=0.06)$ and for postmenopausal women only ( 7 studies; $\mathrm{RE}=1.34 ; 95 \% \mathrm{Cl}=1.06,1.63$, pheterogeneity $=0.30)$.

\section{$E R^{+} P R^{+}$versus ER $P R^{-}$tumors}

Although risk among postmenopausal women was statistically significantly increased for both $\mathrm{ER}^{+} \mathrm{PR}^{+}$and $E \mathrm{R}^{-} \mathrm{PR}$ - tumors, adult weight gain was associated with a statistically significantly greater risk for $E R^{+} P R^{+}$than $E R^{-} P R^{-}$tumors

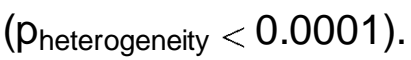

$E R^{+} P R$ and $E R^{-} P R^{+}$tumors 
The association between adult weight gain and risk for $\mathrm{ER}^{+} \mathrm{PR}^{-}$breast tumors was only assessed in postmenopausal women. Fixed effects models were used and no statistically significant association was found (4 studies; $R E=1.04,95 \% \mathrm{CI}=$ $\left.0.68,1.40, p_{\text {heterogeneity }}=0.81\right)$. Associations for $\mathrm{ER}^{-} \mathrm{PR}^{+}$tumors could not be assessed due to the small number of studies and the limited number of cases ( 3 studies).

\section{Publication bias}

Funnel plots were relatively symmetrical (data not shown) and no evidence for publication bias was found for $E R^{+} P R^{+}, E R^{-} P R^{-}$and $E R^{+} P R^{-}$tumors (Egger's test: $p=$ $0.96, p=0.19$, and $p=0.30$, respectively).

\section{DISCUSSION}

This meta-analysis shows that the association between adult weight gain and postmenopausal breast cancer risk is heterogeneous according to ER/PR status of the tumor. Higher adult weight gain was associated with higher risk for $\mathrm{ER}^{+} \mathrm{PR}^{+}$ postmenopausal breast cancer and risk for $\mathrm{ER}^{-} \mathrm{PR}^{-}$postmenopausal breast cancer was only slightly increased. No association with $E R^{+} P R^{-}$postmenopausal breast cancer risk was observed.

A previous meta-analysis on BMI found that higher BMI was associated with higher risk for $\mathrm{ER}^{+} \mathrm{PR}^{+}$tumors in postmenopausal women, but not with risk for $\mathrm{ER}^{-}$ $\mathrm{PR}^{-}$tumors [3]. In our current meta-analysis, adult weight gain was associated with higher risk for both $\mathrm{ER}^{+} \mathrm{PR}^{+}$and $\mathrm{ER}^{-} \mathrm{PR}^{-}$postmenopausal breast cancer, although risk was statistically significantly higher for $\mathrm{ER}^{+} \mathrm{PR}^{+}$compared to $E \mathrm{R}^{-} \mathrm{PR}^{-}$tumors. Both BMI [3] and adult weight gain were not associated with $\mathrm{ER}^{+} \mathrm{PR}^{-}$ 
postmenopausal breast cancer risk. The association of BMI [3] and adult weight gain with $\mathrm{ER}^{-} \mathrm{PR}^{+}$postmenopausal breast cancer could not be reliably assessed due to the limited number of studies. No studies were available on adult weight gain and risk of premenopausal breast cancer by ER/PR status, and therefore this association could not be independently assessed.

$\mathrm{BMI}$ is the most commonly used anthropometric measure to define obesity, and has been consistently associated with increased postmenopausal breast cancer risk [1]. However, adult weight gain is thought to be a better measure to assess adiposity and its metabolic consequences than BMI. Whereas BMI reflects both lean body mass and adipose mass, weight gain in adult life is generally a gain of body fat and thus potentially represents the age-related metabolic change that may be important in breast cancer development [4]. Several studies examining both adult weight gain and adult BMI in the same study population have found weight gain to be an equivalent $[5,6]$ or stronger $[4,7-10]$ predictor of postmenopausal breast cancer risk than recent BMI.

In postmenopausal women, obesity has been associated with hyperinsulinaemia and insulin resistance, and with elevated estradiol and lower SHBG levels [30]. Similar associations have been found for adult weight gain [31]. Hyperinsulinaemia and insulin resistance, among other factors, may promote both $\mathrm{ER}^{+} \mathrm{PR}^{+}$and $\mathrm{ER}^{-} \mathrm{PR}^{-}$breast tumors in postmenopausal women. The stronger associations found for adult weight gain in relation to risk for $\mathrm{ER}^{+} \mathrm{PR}^{+}$compared with ER ${ }^{-} R^{-}$postmenopausal breast cancer may be explained by an additional promoting effect of higher free estradiol levels on $E R^{+} P R^{+}$breast tumors, specifically.

Although this meta-analysis shows that adult weight gain is clearly associated with increased risk for $\mathrm{ER}^{+} \mathrm{PR}^{+}$breast cancer and to a lesser extent with increased 
risk for $\mathrm{ER}^{-} \mathrm{PR}^{-}$breast cancer in postmenopausal women, we observed large heterogeneity between the study-specific risk estimates, in particular for $E R^{+} P R^{+}$ breast tumors. One possible explanation for this heterogeneity may be differences in the definition of quantiles between studies, which preclude relating risk for $E \mathrm{R}^{+} \mathrm{PR}^{+}$ or $\mathrm{ER}^{-} \mathrm{PR}^{-}$breast tumors to specific cut-off measurements of adult weight change. However, the heterogeneity between studies may be due to several other reasons.

Studies were performed in different age groups and adult weight gain has been previously shown to be differentially related to premenopausal and postmenopausal breast cancer risk [11]. Indeed, restricting the studies to those conducted in postmenopausal women reduced heterogeneity.

Further, there is a potential for measurement error from self-reported weight and recall of weight during early adulthood. However, correlations between measured and self-reported weight typically are $>0.95$ [11], and correlations between recalled weight over several decades and measured weight have been between 0.80 and 0.87 in several studies [32].

The assay methods for the measurement of ER/PR status and cutoff points for ER/PR status were not available for all studies and also varied across/within studies. This may have led to misclassification of the tumor subtypes and in consequence to attenuation of the observed risk estimates. Some studies only reported on ER and PR status separately whereas other studies considered joint ER/PR status. The combination of ER and PR status is reflective of true tumor estrogen dependence, since tumors will be both ER and PR positive if expression of the PR gene is induced by the presence of a normally functioning ER-estradiolbinding system [33]. Restricting our meta-analyses to studies measuring joint ER/PR status increased the risk estimates. 
Current use of hormone replacement therapy increases circulating estrogen levels and may obscure the effect of adult weight gain on postme nopausal breast cancer risk. Some studies restricted their study population of postmenopausal women to non-users of postmenopausal hormones $[12-14,19]$ while other studies adjusted for postmenopausal hormone use $[15,17,18]$. However, results for adult weight gain and postmenopausal breast cancer risk did not appear to differ between the two types of studies.

Associations may be different for different ethnic groups. In black women, adult weight gain was not statistically significantly associated with $E R^{+} P R^{+}$ postmenopausal breast cancer risk [14]. It may also be possible that it was more difficult to detect this association in black women due to the smaller study population and the lower proportion of breast carcinomas that are $\mathrm{ER}^{+}, \mathrm{PR}^{+}$, or both.

To account for baseline differences in body size, some studies adjusted the analyses for baseline weight and height or BMI $[13,14,16,17]$. The other studies either adjusted for recent BMI $[18,19]$, or did not perform any adjustment for body size $[12,15,20]$. However, results did not appear differ for studies with or without adjustment. Finally, unknown or residual confounding may be present.

The relation between adult weight gain and ER/PR defined breast cancer risk has not yet been fully clarified. To the best of our knowledge, no studies have been conducted in premenopausal women only. Future studies should investigate whether adult weight gain has a differential effect on $\mathrm{ER}^{+} \mathrm{PR}^{+}$premenopausal breast cancer risk, as is suggested by the lower risk estimates in the mixed population of pre- and postmenopausal women combined compared to those in postmenopausal women.

Further, it is unclear whether adult weight gain throughout the entire adulthood lifespan or weight gain during specific life stages is most relevant for the 
observed increase in $\mathrm{ER}^{+} \mathrm{PR}^{+}$defined postmenopausal breast cancer risk. Weight gain during pubertal years is distributed primarily on the hips and buttocks. During later adult life fat accumulates preferentially around the waist. Only few studies have addressed the effect of adult weight gain during multiple life stages with respect to overall postmenopausal breast cancer risk. Three prospective cohort studies and one case-control study showed that both adult weight gain before and after menopause were associated with postmenopausal breast cancer risk [13, 18, 34, 35] whereas in one case-control study an increase in risk was only evident for adult weight gain after menopause [17]. None of these studies investigated whether these associations differed by ER/PR status of the tumor.

In conclusion, the association between adult weight gain and postmenopausal breast cancer risk is heterogeneous according to ER/PR status of the tumor, with higher risk estimates for $\mathrm{ER}^{+} \mathrm{PR}^{+}$than for $\mathrm{ER}^{-} \mathrm{PR}^{-}$tumors. The association of adult weight gain with ER/PR defined premenopausal breast cancer risk could not be independently assessed. These findings suggest that control of body weight may prevent $E R^{+} P R^{+}$tumors, and to a lesser extent ER $\mathrm{PR}^{-}$tumors, after menopause.

\section{ACKNOWLEDGEMENTS}

This work was funded by the Deutsche Krebshilfe, project number 108253. The authors had no conflict of interest. 


\section{REFERENCES}

1. World Cancer Research Fund / American Institute for Cancer Research (2007) Food, Nutrition, Physical Activity, and the Prevention of Cancer: a Global Perspective. AICR, Washington DC

2. Potischman N, Swanson CA, Siiteri P, Hoover RN (1996) Reversal of relation between body mass and endogenous estrogen concentrations with menopausal status. J Natl Cancer Inst 88:756-758.

3. Suzuki R, Orsini N, Saji S, Key TJ, Wolk A (2009) Body weight and incidence of breast cancer defined by estrogen and progesterone receptor status--a meta-analysis. Int J Cancer $124: 698-712$. doi:10.1002/ijc.23943

4. Ballard-Barbash R, Schatzkin A, Taylor PR, Kahle LL (1990) Association of change in body mass with breast cancer. Cancer Res 50:2152-2155.

5. Magnusson C, Baron J, Persson I, Wolk A, Bergstrom R, Trichopoulos D, Adami HO (1998) Body size in different periods of life and breast cancer risk in post-menopausal women. Int J Cancer 76:29-34. doi:10.1002/(SICI)10970215(19980330)76:1<29::AID-IJC6>3.0.CO;2-\#

6. Trentham-Dietz A, Newcomb PA, Egan KM, Titus-Ernstoff L, Baron JA, Storer BE, Stampfer M, Willett WC (2000) Weight change and risk of postmenopausal breast cancer (United States). Cancer Causes Control 11:533-542. doi:10.1023/A:1008961931534

7. Le Marchand L, Kolonel LN, Earle ME, Mi MP (1988) Body size at different periods of life and breast cancer risk. Am J Epidemiol 128:137-152.

8. Brinton LA, Swanson CA (1992) Height and weight at various ages and risk of breast cancer. Ann Epidemiol 2:597-609.

9. Huang Z, Hankinson SE, Colditz GA, Stampfer MJ, Hunter DJ, Manson JE, Hennekens CH, Rosner B, Speizer FE, Willett WC (1997) Dual effects of weight and weight gain on breast cancer risk. JAMA 278:1407-1411.

10. Feigelson HS, Jonas CR, Teras LR, Thun MJ, Calle EE (2004) Weight gain, body mass index, hormone replacement therapy, and postmenopausal breast cancer in a large prospective study. Cancer Epidemiol Biomarkers Prev 13:220-224. doi:10.1158/1055-9965.EPI-03-0301

11. IARC (2002) Weight control and physical activity. IARC Handbooks of cancer prevention, vol 6. IARC Press, Lyon, France

12. Feigelson HS, Patel AV, Teras LR, Gansler T, Thun MJ, Calle EE (2006) Adult weight gain and histopathologic characteristics of breast cancer among postmenopausal women. Cancer 107:12-21. doi:10.1002/cncr.21965

13. Ahn J, Schatzkin A, Lacey JV, Jr., Albanes D, Ballard-Barbash R, Adams KF, Kipnis V, Mouw T, Hollenbeck AR, Leitzmann MF (2007). Adiposity, adult weight change, and postmenopausal breast cancer risk. Arch Intern Med 167:2091-2102. doi:10.1001/archinte.167.19.2091

14. Palmer JR, Adams-Campbell LL, Boggs DA, Wise LA, Rosenberg L (2007) A prospective study of body size and breast cancer in black women. Cancer Epidemiol Biomarkers Prev 16:1795-1802. doi:10.1158/1055-9965.EPI-070336

15. Enger SM, Ross RK, Paganini-Hill A, Carpenter CL, Bernstein L (2000) Body size, physical activity, and breast cancer hormone receptor status: results from two case-control studies. Cancer Epidemiol Biomarkers Prev 9:681-687.

16. Wenten M, Gilliland FD, Baumgartner K, Samet JM (2002) Associations of weight, weight change, and body mass with breast cancer risk in Hispanic and 
non-Hispanic white women. Ann Epidemiol 12:435-444. doi:S1047279701002939

17. Eng SM, Gammon MD, Terry MB, Kushi LH, Teitelbaum SL, Britton JA, Neugut Al (2005) Body size changes in relation to postmenopausal breast cancer among women on Long Island, New York. Am J Epidemiol 162:229237. doi:10.1093/aje/kwi195

18. Han D, Nie J, Bonner MR, McCann SE, Muti P, Trevisan M, Ramirez-Marrero FA, Vito D, Freudenheim JL (2006) Lifetime adult weight gain, central adiposity, and the risk of pre- and postmenopausal breast cancer in the Western New York exposures and breast cancer study. Int $\mathrm{J}$ Cancer 119:2931-2937. doi:10.1002/ijc.22236

19. Rosenberg LU, Einarsdottir K, Friman EI, Wedren S, Dickman PW, Hall P, Magnusson C (2006) Risk factors for hormone receptor-defined breast cancer in postmenopausal women. Cancer Epidemiol Biomarkers Prev 15:24822488. doi:10.1158/1055-9965.EPI-06-0489

20. Slattery ML, Sweeney C, Edwards S, Herrick J, Baumgartner K, Wolff R, Murtaugh M, Baumgartner R, Giuliano A, Byers T (2007) Body size, weight change, fat distribution and breast cancer risk in Hispanic and non-Hispanic white women. Breast Cancer Res Treat 102:85-101. doi:10.1007/s10549-0069292-y

21. Colditz GA, Rosner BA, Chen WY, Holmes MD, Hankinson SE (2004) Risk factors for breast cancer according to estrogen and progesterone receptor status. J Natl Cancer Inst 96 :218-228. doi:10.1093/jnci/djh025

22. R Development Core Team (2008) R: A Language and Environment for Statistical Computing. R Foundation for Statistical Computing, Vienna, Austria

23. Huedo-Medina TB, Sanchez-Meca J, Marin-Martinez F, Botella J (2006) Assessing heterogeneity in meta-analysis: $Q$ statistic or 12 index? Psychol Methods 11:193-206. doi:10.1037/1082-989X.11.2.193

24. Hedges LV, Olkin I (1985) Statistical methods for meta-analysis, Academic Press, New York

25. Whitehead A, Whitehead J (1991) A general parametric approach to the meta-analysis of randomized clinical trials. Stat Med 10:1665-1677.

26. DerSimonian R, Laird N (1986) Meta-analysis in clinical trials. Control Clin Trials 7:177-188. doi:0197-2456(86)90046-2

27. Light RJ, Pillemer DB (1984) Summing up. The science of reviewing research. Harvard University Press, Cambridge

28. Sterne JA, Egger M (2001) Funnel plots for detecting bias in meta-analysis: guidelines on choice of axis. J Clin Epidemiol 54:1046-1055. doi:S08954356(01)00377-8

29. Egger M, Davey Smith G, Schneider M, Minder C (1997) Bias in metaanalysis detected by a simple, graphical test. BMJ 315:629-634.

30. Calle EE, Kaaks R (2004) Overweight, obesity and cancer: epidemiological evidence and proposed mechanisms. Nat Rev Cancer 4:579-591. doi:10.1038/nrc1408

31. Stoll BA (1995) Timing of weight gain in relation to breast cancer risk. Ann Oncol $6: 245-248$.

32. Willett WC (1998) Nutritional epidemiology. Oxford University Press, New York 
33. Rose DP, Vona-Davis L (2009) Influence of obesity on breast cancer receptor status and prognosis. Expert Rev Anticancer Ther 9:1091-1101. doi:10.1586/era.09.71

34. Harvie M, Howell A, Vierkant RA, Kumar N, Cerhan JR, Kelemen LE, Folsom AR, Sellers TA (2005) Association of gain and loss of weight before and after menopause with risk of postmenopausal breast cancer in the lowa women's health study. Cancer Epidemiol Biomarkers Prev 14:656-661. doi:10.1158/1055-9965.EPI-04-0001

35. Eliassen AH, Colditz GA, Rosner B, Willett WC, Hankinson SE (2006) Adult weight change and risk of postmenopausal breast cancer. JAMA 296:193201. doi:10.1001/jama.296.2.193 
Table 1 Characteristics of prospective cohort and case-control studies on weight gain from age 15, 18, 20 or 50 to referent age and breast cancer incidence by ER/PR status

\begin{tabular}{|c|c|c|c|c|c|c|c|}
\hline $\begin{array}{l}\text { Author, year, } \\
\text { country, major } \\
\text { ERPR assay } \\
\text { [ref] }\end{array}$ & $\begin{array}{l}\text { Design (study } \\
\text { name), follow-up / } \\
\text { yr-data collection, } \\
\text { no. of overall } \\
\text { cases and (study } \\
\text { size) / controls }\end{array}$ & $\begin{array}{l}\text { Age and } \\
\text { menopau- } \\
\text { sal status }\end{array}$ & $\begin{array}{l}\text { Type of } \\
\text { tumor }\end{array}$ & $\begin{array}{l}\text { ER/PR defined } \\
\text { cases number } \\
\text { (approxim ate \% } \\
\text { known receptor) }\end{array}$ & $\begin{array}{l}\text { Exposure measurement (kg } \\
\text { unless otherw ise stated) }\end{array}$ & $\begin{array}{l}\text { Effect } \\
\text { estimates }\end{array}$ & Adjusted factors \\
\hline \multirow{3}{*}{$\begin{array}{l}\text { Prospective coh } \\
\text { Feigelson, } \\
\text { 2006, US, N.A. } \\
{[12]}\end{array}$} & t studies & & & & & & \multirow{3}{*}{$\begin{array}{l}\text { Age, age at menarche, age at menopause, } \\
\text { number of live births, age at first live birth, } \\
\text { use of OC, family history of breast cancer, } \\
\text { history of breast cysts, history of } \\
\text { mammography, height, education, physical } \\
\text { activity, alcohol intake, aspirin use, race } \\
\text { (excluded PMH user). }\end{array}$} \\
\hline & \multirow{2}{*}{$\begin{array}{l}\text { Prospective coh } \\
\text { (CPS- II), } \\
1992-2001 \\
1,200 \text { cases } \\
(44,161)\end{array}$} & \multirow[t]{2}{*}{$\begin{array}{l}50-74 \mathrm{yr} \\
\text { Post }\end{array}$} & \multirow{2}{*}{$\begin{array}{l}\text { ER+PR+ } \\
\text { ER+PR-/ } \\
\text { ER-PR+ } \\
\text { ER-PR- }\end{array}$} & $\begin{array}{l}445 \text { cases }(68 \%) \\
108 \text { cases }(17 \%)\end{array}$ & $\begin{array}{l}>27.3 \text { vs. }-2.3 \text { to } 9.1 \text { from age } 18 \\
>27.3 \text { vs. }-2.3 \text { to } 9.1 \text { from age } 18\end{array}$ & $\begin{array}{l}2.42(1.82,3.23) \\
1.32(0.70,2.49)\end{array}$ & \\
\hline & & & & 98 cases $(15 \%)$ & $>27.3$ vs. -2.3 to 9.1 from age 18 & $1.78(0.98,3.23)$ & \\
\hline $\begin{array}{l}\text { Ahn, 2007, US, } \\
\text { N.A. [13] }\end{array}$ & $\begin{array}{l}\text { Prospective coh } \\
\text { (AARP), } \\
1996-2000 \\
2,111 \text { cases } \\
(99,039)\end{array}$ & $\begin{array}{l}50-71 \mathrm{yr} \\
\text { Post }\end{array}$ & $\begin{array}{l}\text { ER+PR+ } \\
\text { ER+PR- } \\
\text { ER-PR+ } \\
\text { ER-PR- }\end{array}$ & $\begin{array}{l}202 \text { cases }(66 \%) \\
44 \text { cases }(14 \%) \\
10 \text { cases }(3 \%) \\
53 \text { cases }(17 \%)\end{array}$ & $\begin{array}{l}\geq 30 \text { vs. }-2.0 \text { to } 9.9 \text { from age } 18 \\
\geq 30 \text { vs. }-2.0 \text { to } 9.9 \text { from age } 18 \\
\geq 30 \text { vs. }-2.0 \text { to } 9.9 \text { from age } 18 \\
\geq 30 \text { vs. }-2.0 \text { to } 9.9 \text { from age } 18\end{array}$ & $\begin{array}{l}2.69(1.74,4.17) \\
1.28(0.47,3.48) \\
- \\
0.61(0.21,1.82)\end{array}$ & $\begin{array}{l}\text { Age, age at menarche, age at menopause, } \\
\text { age at first live birth, parity, smoking, } \\
\text { education, race, family history of breast } \\
\text { cancer, fat intake, alcohol intake, } \\
\text { oophorectomy, physical activity, weight at } \\
\text { age 18, height (excluded PMH user). }\end{array}$ \\
\hline \multirow[t]{2}{*}{$\begin{array}{l}\text { Palmer, 2007, } \\
\text { US, N.A. [14] }\end{array}$} & \multirow{2}{*}{$\begin{array}{l}\text { Prospective coh } \\
\text { (BWHS), } \\
1995-2005 \\
442 \text { cases } \\
(9,542)\end{array}$} & \multirow[t]{2}{*}{$\begin{array}{l}25-79 \mathrm{yr} \\
\text { Post }\end{array}$} & \multirow{2}{*}{$\begin{array}{l}\text { ER+PR+ } \\
\text { ER+PR-/ } \\
\text { ER-PR+ } \\
\text { ER-PR- }\end{array}$} & $\begin{array}{l}82 \text { cases }(48 \%) \\
36 \text { cases }(21 \%)\end{array}$ & $\begin{array}{l}\geq 25 \text { vs. }<15 \text { from age } 18 \\
\geq 25 \text { vs. }<15 \text { from age } 18\end{array}$ & $\begin{array}{l}1.29(0.73,2.28) \\
0.31(0.13,0.77)\end{array}$ & \multirow{2}{*}{$\begin{array}{l}\text { Age, age at menarche, parity, age at first } \\
\text { birth, age at menopause, vigorous activity, } \\
\text { education, family history of breast cancer, } \\
\text { BMl at age } 18 \text { (excluded PMH user). }\end{array}$} \\
\hline & & & & 52 cases $(31 \%)$ & $\geq 25$ vs. $<15$ from age 18 & $1.03(0.52,2.05)$ & \\
\hline \multicolumn{8}{|c|}{ Case-control studies } \\
\hline \multirow[t]{2}{*}{$\begin{array}{l}\text { Enger, 2000, } \\
\text { US, DCC [15] }\end{array}$} & $\begin{array}{l}\text { Population-based } \\
\text { cc } \\
1987-1989\end{array}$ & $\begin{array}{l}55-64 \mathrm{yr} \\
\text { Post }\end{array}$ & $\begin{array}{l}\text { ER+PR+ } \\
\text { ER+PR- } \\
\text { ER-PR+ }\end{array}$ & $\begin{array}{l}450 \text { cases }(59 \%) \\
159 \text { cases }(21 \%) \\
24 \text { cases }(3 \%)\end{array}$ & $\begin{array}{l}\geq 29.2 \text { vs. } \leq 0 \% \text { from age } 18 \\
\geq 29.2 \text { vs. } \leq 0 \% \text { from age } 18 \\
-\end{array}$ & $\begin{array}{l}2.32(1.58,3.41) \\
0.99(0.58,1.78) \\
-\end{array}$ & \multirow{4}{*}{$\begin{array}{l}\text { Age at reference year (matched), } \\
\text { socioeconomic status (matched), number of } \\
\text { full term pregnancy, breast feeding, age at } \\
\text { menopause, use of PMH, family history of } \\
\text { breast cancer, alcohol intake, physical } \\
\text { activity. } \\
\text { Age, family history of breast cancer, total } \\
\text { METS, parity, use of OC, breast feeding, age } \\
\text { at first birth, use of PMH, menopausal status, } \\
\text { weight at age } 18 \text {. }\end{array}$} \\
\hline & $\begin{array}{l}760 \text { cases } \\
1,091 \text { controls }\end{array}$ & & ER-PR- & 127 cases $(17 \%)$ & $\geq 29.2$ vs. $\leq 0 \%$ from age 18 & $1.75(0.91,3.38)$ & \\
\hline \multirow[t]{2}{*}{$\begin{array}{l}\text { Wenten, 2002, } \\
\text { US, N.A. [16] }\end{array}$} & \multirow{2}{*}{$\begin{array}{l}\text { Population-based } \\
\text { cc } \\
1992-1994 \\
694 \text { cases } \\
813 \text { controls }\end{array}$} & $\begin{array}{l}\text { 30-74yr } \\
\text { Mixed } \\
\text { NHW }\end{array}$ & $\begin{array}{l}\text { ER+PR+ } \\
\text { ER-PR- }\end{array}$ & $\begin{array}{l}133 \text { cases } \\
77 \text { cases }\end{array}$ & $\begin{array}{l}>14 \text { vs. }<4 \text { from age } 18 \\
>14 \text { vs }<4 \text { from age } 18\end{array}$ & $\begin{array}{l}1.05(0.60,1.84) \\
0.93(0.42,2.05)\end{array}$ & \\
\hline & & Hispanic & $\begin{array}{l}\text { ER+PR+ } \\
\text { ER-PR- }\end{array}$ & $\begin{array}{l}133 \text { cases } \\
77 \text { cases }\end{array}$ & $\begin{array}{l}>14 \text { vs. }<4 \text { from age } 18 \\
>14 \text { vs. }<4 \text { from age } 18\end{array}$ & $\begin{array}{l}3.04(1.47,6.26) \\
1.73(0.71,4.25)\end{array}$ & \\
\hline $\begin{array}{l}\text { Eng, } 2005 \text {, US, } \\
\text { N.A. [17] }\end{array}$ & $\begin{array}{l}\text { Population-based } \\
\text { cc } \\
1996-1997 \\
990 \text { cases } \\
1,006 \text { controls }\end{array}$ & $\begin{array}{l}20-98 \mathrm{yr} \\
\text { Post }\end{array}$ & $\begin{array}{l}\text { ER+PR+ } \\
\text { ER+PR- } \\
\text { ER-PR+ } \\
\text { ER-PR- }\end{array}$ & $\begin{array}{l}387 \text { cases }(58 \%) \\
121 \text { cases }(18 \%) \\
30 \text { cases }(4 \%) \\
132 \text { cases }(20 \%)\end{array}$ & $\begin{array}{l}\geq 11.3 \text { vs. } 0 \text { from age } 50 \\
\geq 11.3 \text { vs. } 0 \text { from age } 50 \\
\geq 11.3 \text { vs. } 0 \text { from age } 50 \\
\geq 11.3 \text { vs. } 0 \text { from age } 50\end{array}$ & $\begin{array}{l}2.17(1.38,3.42) \\
1.25(0.57,2.74) \\
1.54(0.38,6.35) \\
1.50(0.72,3.13)\end{array}$ & $\begin{array}{l}\text { Age at reference date, number of pregnancy, } \\
\text { use of PMH, family history of breast cancer, } \\
\text { history of benign breast disease, BMl at age } \\
50 \mathrm{yr} \text {. }\end{array}$ \\
\hline $\begin{array}{l}\text { Han, 2006, US, } \\
\text { DCC/IHC [18] }\end{array}$ & $\begin{array}{l}\text { Population-based } \\
\text { cc } \\
1996-2001\end{array}$ & $\begin{array}{l}35-79 \mathrm{yr} \\
\text { Post }\end{array}$ & $\begin{array}{l}\text { ER+ } \\
\text { ER- } \\
\text { PR+ }\end{array}$ & $\begin{array}{l}510 \text { cases }(79 \%) \\
136 \text { cases }(21 \%) \\
389 \text { cases }(60 \%)\end{array}$ & $\begin{array}{l}>27.3 \text { vs. }>0 \text { to } 9.1 \text { from age } 20 \\
>27.3 \text { vs. }>0 \text { to } 9.1 \text { from age } 20\end{array}$ & $\begin{array}{l}2.42(1.62,3.61) \\
1.19(0.58,2.43) \\
3.14(1.96,5.04)\end{array}$ & $\begin{array}{l}\text { Age, education, age at menarche, age at first } \\
\text { birth, previous benign breast disease, family } \\
\text { history of breast cancer, age at menopause, }\end{array}$ \\
\hline
\end{tabular}


841 cases

1,495 controls

Rosenberg

2006, Sweden,

EIA [19]

cC

1993-1995

2,643 cases

3,065 controls

Slattery, 2007, Population-based

US, N.A. [20]
PR- $\quad 257$ cases $(40 \%)$

$\begin{array}{ll}\text { cc } & \text { Mixed } \\ 1999-2004 & \text { NHW } \\ 2,325 \text { cases } & \end{array}$

$50-74$ y

Post

ER+PR+ 622 cases $(62 \%)$

ER+PR- 156 cases $(16 \%$

ER-PR+ 34 cases ( $3 \%)$

ER-PR- 189 cases $(19 \%)$

Hispanic
$>27.3$ vs. $>0$ to 9.1 from age 20 $>27.3$ vs. $>0$ to 9.1 from age 20

$\geq 30$ vs. $0-9.5$ from age 18

$\geq 30$ vs. $0-9.5$ from age 18

$\geq 30$ vs. $0-9.5$ from age 18

$\geq 30$ vs. $0-9.5$ from age 18

ER+ $\quad 801$ cases $(80 \%) \quad>25$ vs. $\leq 5$ from age 15

ER- $\quad 195$ cases $(20 \%) \quad>25$ vs. $\leq 5$ from age 15

$\mathrm{ER}_{+} \quad 379$ cases $(74 \%) \quad>25$ vs. $\leq 5$ from age 15
$1.21(0.73,2.01) \quad B M l$ residuals, use of $\mathrm{PMH}$

$2.7(1.9,3.8)$

$0.8(0.4,1.7)$

$2.1(0.6,6.8)$

$1.0(0.5,2.1)$

Age, recent BMl, age at first birth (excluded $\mathrm{PMH}$ user).

Age (matched), height, physical activity

energy intake, parity, alco

$1.13(0.85,1.50)$ age at first pregnancy, age at menoption,

$1.81(1.07,3.08) \quad$ menopausal status, estrogen status, center.

$0.72(0.35,1.49)$

AARP $=$ National Institutes of Health - AARP cohort, BMl = body mass index, BWHS = Black Women's Health Study, cc = case-control study, coh $=$ cohort study, CPS-II = the American Cancer Society's Prevention Study II, DCC = dextran-coated charcoal assay / biochemical, EIA = enzyme linked immunoassay, $I H C=$ immunohistochemistry method $/$ immunoperoxidase, mixed $=$ pre- and postmenopausal, N.A = not available, NHS I = Nurses' Health Study I, NHW = non-Hispanic white, OC = oral contraceptives, PMH = postmenopausal hormone, post $=$ postmenopausal, US $=$ United States 
Table 2 Results of the meta-analysis for adult weight gain and $E R^{+} P R^{+}$and $E R^{-} P R^{-}$ breast cancer risk

\begin{tabular}{|c|c|c|c|c|c|c|}
\hline Group & $\begin{array}{l}\text { No. of } \\
\text { studies }\end{array}$ & $T^{2 a}$ & Pheterogeneity $^{D}$ & $T^{2 C}$ & $\begin{array}{l}\text { Model } \\
\text { used }\end{array}$ & $\begin{array}{l}\text { Pooled estimate } \\
\qquad(95 \% \mathrm{Cl})\end{array}$ \\
\hline \multicolumn{7}{|c|}{ Adult weight change, $E R+P R+$} \\
\hline All studies & 11 & 0.44 & $<0.0001$ & $91 \%$ & REM & $2.03(1.62,2.45)$ \\
\hline Mixed & 4 & 0.42 & $<0.0001$ & $88 \%$ & REM & $1.54(0.86,2.22)$ \\
\hline Postmenopausal & 7 & 0.10 & 0.0024 & $71 \%$ & REM & $2.33(2.05,2.60)$ \\
\hline
\end{tabular}

Adult weight change, ER-PR-

$\begin{array}{lcccccc}\text { All studies } & 11 & 0.07 & 0.14 & 32 \% & \text { FEM } & 1.36(1.14,1.58) \\ \text { Mixed } & 4 & 0.20 & 0.06 & 60 \% & \text { REM } & 1.32(0.74,1.89) \\ \text { Postmenopausal } & 7 & 0.03 & 0.30 & 17 \% & \text { FEM } & 1.34(1.06,1.63)\end{array}$

${ }^{\mathrm{a}}{ }^{2}$ is an estimator of between-studies variance.

${ }^{b} p$-values (two-sided) were based on the $Q$ statistic of heterogeneity.

${ }^{c} \mathrm{I}^{2}$ quantifies the percentage of variation across studies that is due to heterogeneity rather than chance.

FEM = fixed effects model, mixed $=$ pre - and postmenopausal women combined, $\mathrm{REM}=$ random effects model . 
Figure 1 Association between adult weight gain and $E R^{+} P R^{+}$breast cancer risk

Figure 2 Association between adult weight gain and $E R^{-} \mathrm{PR}^{-}$breast cancer risk

Footnote to Figures:

Relative samples sizes are represented by size of symbols. Horizontal lines indicate $95 \% \mathrm{Cl}$ for the respective RE. Pooled REs are illustrated by diamonds. Cut-off values ranged from 11.3 to $30 \mathrm{~kg}$ for the highest quantiles and 0 to $15 \mathrm{~kg}$ for the lowest quantiles, respectively. Mixed $=$ pre- and postmenopausal combined, post = postmenopausal.

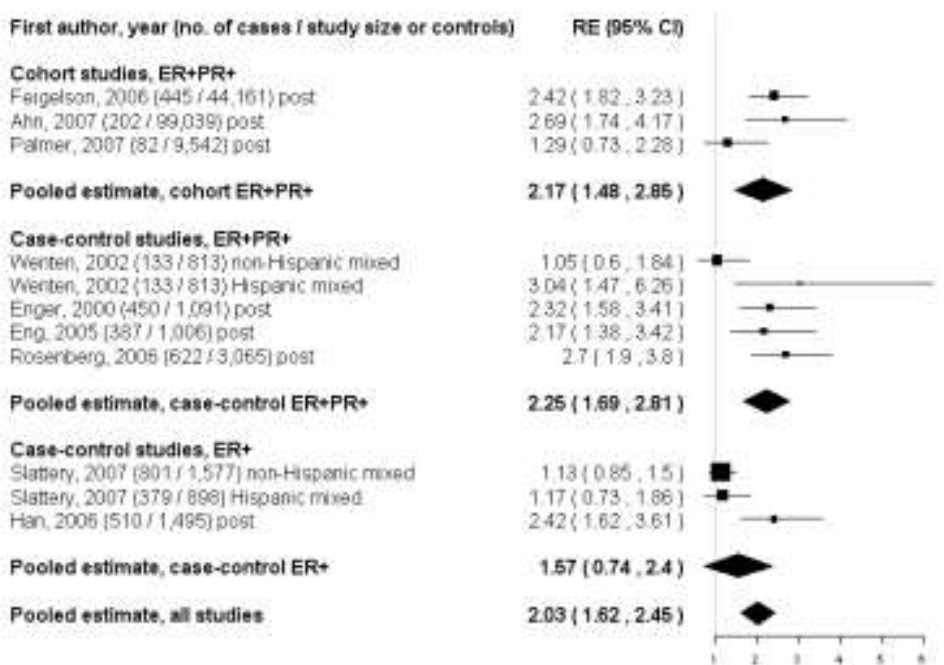


First auther, year (ne of cases i study size or controts)

Cohort studies, ER-PR-

Feigelson, 2006 is8 ; 44, 161) pos

Ahn, 2007 i53/g9 039/ post

Famer, 2007 152/9.542100st

Pooled estimate, cohort ER-PR.

Case-control studies, ER PR.

Wenten, 2002 (77 / 813) non. Hisperic mared

Werten, $2002\langle 77 / 813\rangle$ Hspenic move

Enger, $2000(127 / 1$, gat) post

Ena. 2005 $(132 / 1,006)$ pest
Roserberg. 2005 $[189 / 3,065)$ Dost

Pooled estimate, Ease-control ER.PR.

Case-control studies, ER-

Sattery, 2007 [ $195 \times 1,577]$ nan-Haspenic mered

Stattery, 2007 (130) 898) Hispanic mived

Han, $2005\{136 / 1,495\}$ post

Pooled estimate, case-control ER.

Pooled estimate, all studies
RE $\{95 \%$ C)

$178(0.98 .323)$

$1.03\{0.52 .205\}=$

$1.23(0.57,19)$

$0.83(0.42 .205)$

$\left\{\begin{array}{l}03(0.71 .425\} \\ 175<0.94 .328)\end{array}\right.$

$15(038.835)$

$\longrightarrow$

$1|05,2.1|$

$1.37(1,1.73)$

$181\langle 107.308\}$

$0.72\langle 0.35,149\}$
$1.19\langle 0.58 .243\}$

$1.28(0.53,1.93)$

$1.36(1.14,1.58)$ 